\title{
Prevalence, Outcomes, and Management of Ventricular Arrhythmias in COVID-19 Patients
}

Nicola Tarantino, MDª, Domenico G. Della Rocca, MD ${ }^{b}$, Fengwei Zou, MD ${ }^{a}$, Aung Lin, $\mathrm{MD}^{a}$, Andrea Natale, $\mathrm{MD}^{\mathrm{b}, c, d}$, Luigi Di Biase, $M D, \mathrm{PhD}^{\mathrm{a}, \mathrm{b}, *}$

\section{KEYWORDS}

- Arrhythmias • COVID-19 • Complications • Management • Outcomes • SARS-CoV-2

- Ventricular tachycardia

\section{KEY POINTS}

- Ventricular arrhythmias (VAs) affect a modest proportion of patients with SARS-CoV-2, sometimes representing the only initial symptom.

- The cause of VAs in the setting of acute COVID-19 infection is multifactorial because of direct and indirect myocardial involvement.

- Admission to ICU, use of pressors, pre-existing cardiac disease, but neither QT interval nor left ventricular ejection fraction are consistently associated with such complication.

- Sustained VAs correlate with increased mortality, albeit most of the cardiac arrests originate from not-shockable rhythms.

- Treatment options include correction of metabolic disorder, discontinuation of QT-prolonging agents, antiarrhythmics (especially amiodarone), and ablation in case of a ventricular storm.

\section{INTRODUCTION}

At the time of writing the present article, SARSCoV-2, aka COVID-19, has reportedly hit almost 180 million people globally in less than 18 months since its official identification and disclosure as pandemic. ${ }^{1}$ Initially announced as a severe acute respiratory syndrome due to a novel strain of coronavirus, after the acronym SARS-CoV-2, the first pandemic of the third millennium was unexpectedly far from being an isolated respiratory condition. Instead, a multitude of signs and symptoms, sometimes representing the only atypical manifestation of the disease, have been described with alacrity, making the COVID-19 indeed configuring as a systemic disease requiring a multidisciplinary care.

Pertaining to the cardiovascular complications or manifestations of the SARS-CoV-2, in the present article, we offer an overview of the ventricular arrhythmias related to acute COVID-19 infections, discussing the prevalence, the possible mechanisms due to direct or indirect virus involvement, and the currently proposed therapeutic options.

\footnotetext{
Funding: None declared.

a Montefiore Medical Center, 111 E 210th street, Bronx, NY 10467, USA; ${ }^{\text {b }}$ Texas Cardiac Arrhythmia Institute at St. David's Medical Center, 3000 N I-35, Suite 720, Austin, TX 78705, USA; ${ }^{c}$ Scripps Interventional Car, 9834 Genesee Ave, La Jolla, CA 92037, USA; ${ }^{d}$ Health Education Campus, 9501 Euclid Ave, Cleveland, OH 44106, USA * Corresponding author. Montefiore Medical Center, 111 E 210th street, Bronx, NY 10467, USA

E-mail address: dibbia@gmail.com
} 


\section{EPIDEMIOLOGY AND CLINICAL OUTCOMES Prevalence and Nature of VAs}

Mitacchione and colleagues described the first case of ventricular storm (12 episodes of sustained ventricular tachycardias [VTs]) with concomitant COVID-19 infection in a patient with defibrillator (ICD) and ischemic cardiomyopathy (ejection fraction $=34 \%$ ) admitted to an Italian hospital for respiratory distress. $^{2}$ ICD interrogation showed sustained and nonsustained monomorphic VTs since days before the admission. The authors excluded iatrogenic causes because the systemic use of QT-prolonging immunomodulators and antimicrobials was not recommended at that time, and the VT was probably due to other mechanisms (see paragraph 4). This insightful report suggests that VAs could be the first sign of latent infection in susceptible patients with structural heart disease.

In addition, two descriptions of polymorphic ventricular tachycardia (PMVT) in the settings of prolonged and normal QT, respectively, were also reported..$^{3,4}$ Of interest, two separate cases of newly diagnosed Brugada syndrome were reported, one presenting as an asymptomatic coved-type pattern during febrile peak, ${ }^{5}$ and the other as PMVT due to fever and drug-induced bradycardia. $^{6}$

The overall prevalence of VAs in COVID-19 patients ranges between $0.15 \%$ and $8 \%$ (Table 1). ${ }^{7,8}$ Such a discrepancy stems from the definition of VAs and subpopulations analyzed. The first series by Guo showed that malignant arrhythmias were relatively more common in patients with cardiac injury-defined as troponin T elevation-(11\% vs $5 \%$ over a total of 187 individuals). ${ }^{8} \mathrm{~A}$ retrospective study of 700 patients differentiated the prevalence between patients admitted to intensive care unit (ICU) compared with nonintensive care settings. $^{7}$ In total, only one patient had a lifethreatening torsade de pointes (TdP) in ICU ( $1.4 \%$ vs none in the comparison group). Similarly, nonsustained episodes were more common in critical patients ( $8 \%$ vs $0.6 \%)$. In line with this analysis, a Scandinavian group observed that incidence of VAs in ICU patients was about 3\% ( $n=2 / 155),{ }^{9}$ yet, according to a larger cohort of 1053 hospitalized patients, nonsustained episodes are far less prevalent than malignant VAs $(0.7 \%$ vs $\approx 3 \%) .^{10}$

Lastly, no data are currently available in regard to VAs incidence in COVID-19 patients with implanted cardiac devices treated conservatively at home. In this regard, it is worth carrying out such analysis, as experienced in different settings. ${ }^{11}$

\section{Clinical Value and Outcomes}

Despite the slight numerical divergence, it is worth noting that the occurrence of VAs consistently clustered with complicated hospitalizations, suggesting that ventricular arrhythmias are a marker of severe systemic disease. ${ }^{7,10}$ Indeed, besides anecdotic cases of VA survivors, ${ }^{2-4,6}$ the mortality at 1 month is substantially higher in patients experiencing arrhythmias of ventricular nature (VT or ventricular fibrillation [VF], $59 \%$ vs $16 \%$ in controls; $P<.001$, respectively). ${ }^{10}$ On the contrary, nonsustained episodes of VAs do not seem to predict mortality within a year. ${ }^{7}$

Furthermore, another detailed breakdown of the relationship between VAs and clinical outcomes argues against the role of malignant VTs as the primary/initial cause of death. For instance, as reported by two different groups, a nonshockable rhythm was the predominant cause of cardiac arrest/death (90\% in both studies). ${ }^{7,10}$ Correspondingly, in a series of 140 patients admitted on telemetry monitor, fatal VAs were noted in only $12 \%$ of deceased patients $(6 / 52) .{ }^{12}$ All the events were represented by VF, 1 patient survived, and 2 autopsy examinations suggested that the initial cause of death was pulmonary rather than cardiac.

The prevalence and clinical significance of premature ventricular contractions (PVCs) in the setting of acute infection were less investigated; although subjects with SARS-CoV-2 infection can initially complain of palpitations $(7 \%),{ }^{13}$ dedicated analysis is scarce. An Italian study showed that $4 \%(n=13 / 324)$ of COVID-19 positive subjects admitted to the emergency department presented ventricular ectopy, ${ }^{14}$ compared to $13 \%$ of 1053 hospitalized patients $(n=137) .{ }^{10}$ Despite the evidence that PVCs are seen in cases of novel coronavirus-related myocarditis, ${ }^{15,16}$ the positive predictive value for cardiac involvement is poor, ${ }^{17}$ and likewise the association with mortality is borderline $(\mathrm{HR}=2.79 ; 95 \% \mathrm{Cl}, 1.00-7.79$; $P=.051){ }^{14}$

\section{MECHANISMS AND PREDICTORS OF VAS IN THE SETTING OF ACUTE COVID-19 INFECTION}

A broad number of articles discuss the possible causes of VAs during acute COVID-19. For the sake of simplification, herein we distinguish between intrinsic and extrinsic causes, depending on the direct or indirect role of the pathogenic agent. The formers can be divided into 2 types: primary intrinsic (directly due to the interaction between the virus and the cardiomyocyte) and secondary intrinsic (after the immune response to the systemic infection; Fig. 1). Overall, rarely a 


\begin{tabular}{|c|c|c|c|c|c|c|c|}
\hline $\begin{array}{l}\text { Author } \\
\text { and Date }\end{array}$ & Sample & $\begin{array}{l}\text { Number and } \\
\text { Type of VA }\end{array}$ & $\begin{array}{l}\text { QT/QT-Prolonging } \\
\text { Agents }\end{array}$ & $\begin{array}{l}\text { Underlying } \\
\text { Cardiac Disease }\end{array}$ & $\begin{array}{l}\text { Primary Cause } \\
\text { Hypothesized }\end{array}$ & Management & Outcome \\
\hline $\begin{array}{l}\text { Mitacchione } \\
\text { et } \mathrm{al}^{2}{ }^{2} 2020\end{array}$ & 1 & VT storm & $\begin{array}{l}\text { - NS } \\
\text { - none }\end{array}$ & ICM & $\begin{array}{l}\text { - Systemic } \\
\text { inflammation } \\
\text { - Pre-existing car- } \\
\text { diac disease }\end{array}$ & $\begin{array}{l}\text { VT ablation } \\
\text { with remote } \\
\text { navigation } \\
\text { control } \\
\end{array}$ & Discharged \\
\hline $\begin{array}{l}\text { Elsad } \\
\text { et al, }{ }^{3} 2020\end{array}$ & 1 & $\begin{array}{l}\text { Bradycardia- } \\
\text { induced TdP; } \\
\text { VF }\end{array}$ & $\begin{array}{l}\text { - } 650 \mathrm{~ms} \\
\text { - none }\end{array}$ & None & Multiorgan failure & $\begin{array}{l}\text { Lidocaine } \\
\text { Magnesium } \\
\text { Dopamine } \\
\text { Transcutaneous } \\
\text { pacing } \\
\end{array}$ & Discharged \\
\hline $\begin{array}{l}\text { O'Brien } \\
\text { et al, }{ }^{4} 2020\end{array}$ & 1 & PMVT & $\begin{array}{l}\text { - } 460 \mathrm{~ms} \\
\text { - Hydroxymorphone } \\
\text { - Amiodarone } \mathrm{a}^{\mathrm{a}} \\
\text { - Trazodone }\end{array}$ & None & Multiorgan failure & $\begin{array}{l}\text { Discontinuation of } \\
\text { amiodarone } \\
\text { Lidocaine } \\
\text { Metoprolol }\end{array}$ & Demise \\
\hline $\begin{array}{l}\text { Chang } \\
\text { et al. }{ }^{5} 2020\end{array}$ & 1 & NS & NS & Brugada & $\begin{array}{l}\text { - Systemic } \\
\text { inflammation } \\
\text { - Fever } \\
\text { - Congenital } \\
\text { channelopathy }\end{array}$ & Observation & Discharged \\
\hline $\begin{array}{l}\text { Tsimpoulis } \\
\text { et al, }{ }^{6} 2020\end{array}$ & 1 & PMVT & $\begin{array}{l}\text { - } 422 \mathrm{~ms} \\
\text { - } \mathrm{HCQ} \\
\text { - } \mathrm{AZT} \\
\text { - Propofol } \\
\text { - Dexmedetomidine }\end{array}$ & Brugada & $\begin{array}{l}\text { - Systemic } \\
\text { inflammation } \\
\text { - Fever } \\
\text { - Congenital } \\
\text { channelopathy } \\
\text { - Pressors } \\
\end{array}$ & Supportive care & Demise \\
\hline $\begin{array}{l}\text { Bathla } \\
\quad \text { et } \text { al, }^{7} 2020\end{array}$ & 700 & $\begin{array}{l}\text { - } 1 \mathrm{TdP} \\
\text { - } 10 \mathrm{NSVT}\end{array}$ & $\begin{array}{l}\text { - NS } \\
\text { - NS }\end{array}$ & $\begin{array}{l}\text { - De novo left } \\
\text { ventricular } \\
\text { dysfunction } \\
\text { - NS } \\
\end{array}$ & - Multiorgan failure & NS & $\begin{array}{l}\text { - } 10 \text { survived } \\
\text { - } 1 \text { demise }\end{array}$ \\
\hline $\begin{array}{l}\text { Guo } \\
\text { et } \text { al, }^{8} 2020\end{array}$ & 187 & $11 \mathrm{VT} / \mathrm{VF}$ & $\begin{array}{l}\text { - NS } \\
\text { - NS }\end{array}$ & NS & $\begin{array}{l}\text { - Systemic } \\
\text { inflammation } \\
\text { - Cardiac injury } \\
\end{array}$ & NS & NS \\
\hline
\end{tabular}




\begin{tabular}{|c|c|c|c|c|c|c|c|}
\hline $\begin{array}{l}\text { Author } \\
\text { and Date }\end{array}$ & Sample & $\begin{array}{l}\text { Number and } \\
\text { Type of VA }\end{array}$ & $\begin{array}{l}\text { QT/QT-Prolonging } \\
\text { Agents }\end{array}$ & $\begin{array}{l}\text { Underlying } \\
\text { Cardiac Disease }\end{array}$ & $\begin{array}{l}\text { Primary Cause } \\
\text { Hypothesized }\end{array}$ & Management & Outcome \\
\hline $\begin{array}{l}\text { Peltzer } \\
\text { et al, }{ }^{10} 2020\end{array}$ & 1053 & $\begin{array}{l}\text { - } 137 \text { PVC } \\
\text { - } 7 \text { NSVT } \\
\text { - } 13 \text { VT } \\
\text { - } 9 \text { PMVT } \\
\text { - } 8 \text { VF } \\
\end{array}$ & $\begin{array}{l}\text { - NS/ } 4 \text { of the } 745 \\
\text { using } \mathrm{HCQ}^{+} \text {had } \\
\text { PMVT }\end{array}$ & NS & $\begin{array}{l}\text { - Multiorgan failure } \\
\text { - Pressors }\end{array}$ & NS & $\begin{array}{l}59 \% \text { of patients with } \\
\text { VA died }\end{array}$ \\
\hline $\begin{array}{l}\text { Turagam } \\
\text { et al, }{ }^{11} 2020\end{array}$ & 140 & $\begin{array}{l}\text { - } 6 \mathrm{VF} \\
\text { - } 1 \mathrm{VT}\end{array}$ & $\begin{array}{l}\text { - } \mathrm{NS} \\
\text { - } 107 / 140 \text { used HCQ; } \\
-62 / 140 \text { used } \\
\text { HCQ + AZT }\end{array}$ & NS & $\begin{array}{l}\text { - Multiorgan failure/ } \\
\text { pressors (5/7) } \\
\text { - NS in one VF } \\
\text { patient } \\
\text { - Pre-existing car- } \\
\text { diac disease (VT } \\
\text { patient) }\end{array}$ & NS & $\begin{array}{l}\text { - } 6 \text { demises (VF } \\
\text { group) } \\
\text { - } 1 \text { survived (VT } \\
\text { patient) }\end{array}$ \\
\hline $\begin{array}{l}\text { Lanza } \\
\text { et al, }{ }^{14} 2021\end{array}$ & 324 & 13 PVC & $\begin{array}{l}\text { - NS } \\
\text {-NS } \\
\end{array}$ & NS & NS & NS & 4 demises \\
\hline $\begin{array}{l}\text { Perretto } \\
\text { et al, }{ }^{15} 2021\end{array}$ & 7 & $\begin{array}{l}\text { - } 2 \text { PVC/NSVT } \\
\text { - } 1 \mathrm{VT} \\
\text { - } 1 \mathrm{VF}\end{array}$ & $\begin{array}{l}\text { - Normal; } \\
\text { - HCQ/AZT in } 3 / 4 \text { pts } \\
\text { with VAs }\end{array}$ & CAD & $\begin{array}{l}\text { - Myocarditis } \\
\text { - Pre-existing car- } \\
\text { diac disease } \\
\text { - Pressors }\end{array}$ & $\begin{array}{l}\text { - Amiodarone } \\
\text { in } 1 \text { pt with } \\
\text { NSVT } \\
\text { - Metoprolol/ } \\
\text { Bisoprolol } \\
\text { in the others } \\
\end{array}$ & $\begin{array}{l}\text { Discharged (ICD in pt } \\
\text { with VF and in } 1 \\
\text { with NSVT). All } \\
\text { alive at } 6 \text { months }\end{array}$ \\
\hline $\begin{array}{l}\text { D'Ascenzo }^{\prime} \text { As al, }{ }^{30} 2021 \\
\end{array}$ & 779 & 38 VT/VF & $\begin{array}{l}\text { - NS } \\
\text { - NS } \\
\end{array}$ & CAD & $\begin{array}{l}\text { ACS } \\
\text { Multifactorial }\end{array}$ & NS & NS \\
\hline
\end{tabular}




\begin{tabular}{|c|c|c|c|c|c|c|c|}
\hline $\begin{array}{l}\text { Saleh M, } \\
\quad 2020\end{array}$ & 201 & $\begin{array}{l}\text { - } 7 \text { NSVT } \\
\bullet 1 \mathrm{VT}\end{array}$ & $\begin{array}{l}\text { - NS } \\
\text { - All pts were } \\
\text { treated with HCQ, } \\
119 \text { with also AZT }\end{array}$ & No & $\begin{array}{l}\text { - Myocarditis in pt } \\
\text { with VT } \\
\text { - Hypoxemia and } \\
\text { systemic inflamma- } \\
\text { tion in the others }\end{array}$ & NS & $\begin{array}{l}\text { - } 6 \text { discharged } \\
\text { - } 2 \text { demises (1 with } \\
\text { VT) }\end{array}$ \\
\hline $\begin{array}{l}\text { Gasparetti } A_{1}^{40} \\
2020\end{array}$ & 649 & $\begin{array}{l}\text { - } 3 \mathrm{VF} \\
\text { - } 4 \mathrm{VT}\end{array}$ & $\begin{array}{l}\text { - NS } \\
\text { - All pts were } \\
\text { treated with HCQ }\end{array}$ & $6 \mathrm{ICM}$ & $\begin{array}{l}\text { - ACS in pts with VF } \\
\text { - Multiorgan failure } \\
\text { in the remainder }\end{array}$ & $\begin{array}{l}\text { - } \mathrm{HCQ} \\
\text { discontinuation }\end{array}$ & 3 demises (VF group) \\
\hline
\end{tabular}

Abbreviations: ACS, acute coronary syndrome; AZT, azithromycin; CAD, coronary artery disease; HCQ, hydroxychloroquine; ICM, ischemic cardiomyopathy; NS, nonspecified; NSVT, nonsustained VT; PMVT, polymorphic ventricular tachycardia; pts, patients; PVC, premature ventricular contraction; TdP, torsade de pointes; VF, ventricular fibrillation; VT, ventricular tachycardia.

${ }^{a}$ For atrial fibrillation with rapid ventricular response.

b Due to respiratory failure. 


\section{Arrhythmogenic triggers}

\section{Intrinsic}
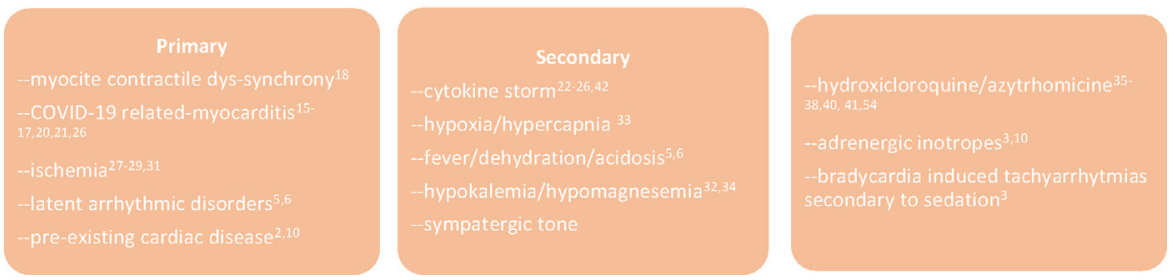

Fig. 1. Schematic classification of VA causes in COVID-19 patients.

single factor can be pointed as the source of VA; instead, plural elements could affect the electrical vulnerability of the ventricles. ${ }^{18}$

\section{Intrinsic Factors}

A brilliant in vitro model showed that infected cardiomyocytes derived from a human pluripotent staminal cell exhibit a significant reduction of the contractile activity measured as beats per minute (4 vs 9 in controls) and a greater extent of contraction dis-synchrony compared with mock SARSCoV-2 negative cultures. ${ }^{19}$ Such effect became even more prominent after 48 hours of treatment with interleukin-6. In fact, even though the presence of the virus in cardiac tissue or evidence of myocarditis have been inconsistently detected, ${ }^{20-22}$ cytokines surge from the systemic immune response are alone sufficient to dysregulate calcium handling, modulate ion channels expression, increase fibrosis, and exert a negative inotropic effect, ultimately enhancing the susceptibility to VAs. ${ }^{23-27}$ For example, late VAs and epicardial fibrosis at the magnetic resonance were documented in one case months after the resolution of the acute illness. ${ }^{28}$

COVID-19 can provoke cardiac ischemia as well, due to both hypoxia/demanding mechanism, ${ }^{29}$ but also as it can eminently be thrombogenic and cause coronary microemboli and acute coronary syndromes (ACSs). ${ }^{30,31}$ The relationship with sustained VAs, however, does not differ from negative controls admitted with ACSs (4.9\% vs $6.8 \%, P=n s) .{ }^{32}$ Beyond the direct involvement of the heart, systemic metabolic derangements such as acidosis, hypercapnia, hypokalemia, dehydration, and catecholamines surge do precipitate VAs. ${ }^{33-37}$ Also, fever can incidentally unmask Brugada pattern in predisposed subjects, ${ }^{5,6}$ and obviously, patients with pre-existing cardiomyopathy are more prone to develop VAs in the setting of SARS-CoV-2 infection. ${ }^{2,10}$

\section{Extrinsic Factors and Predictors of VAs}

VAs can also be iatrogenic. Based on the evidence that hydroxychloroquine and chloroquine inhibit lysosome turnover, and consequently the antigen presentation initiating the immune response, ${ }^{38}$ there has been a large empirical use of antimalarial drugs at the beginning of the pandemic with the purpose to damper the adverse events and the hospitalization duration. However, the most concerning side effects of hydroxychloroquine are QT prolongation and TdP, especially if combined with antimicrobial prophylaxis with azithromycin or lopinavir/ritonavir. ${ }^{39,40}$ Indeed, the duration of phase 2 of the action potential is prolonged through hydroxychloroquine inhibition of the hERG channels, slowing the potassium rapid inward currents (iKr), and by means of sodium current enhancement exerted by azithromycin on SC5NA. ${ }^{41-43}$ Repolarization prolongation by 10 to $50 \mathrm{~ms}$ is relatively frequent $(5 \%-50 \%),{ }^{10,34,35,44}$ and in one series of 201 patients treated with empirical prophylaxis, $18(11 \%)$ developed QTC prolongation greater than $500 \mathrm{~ms}$, albeit only one patient had sustained VT $(0.5 \%)$, and no TdP was recorded. ${ }^{34}$ In another series, no difference in VAs incidence was seen between patients treated with antimalarial agents versus controls, ${ }^{10}$ whereas Gasparetti and colleagues concluded that the 3 VF observed in 28 patients admitted in ICU (10\%) were due to ongoing ACS and not hydroxychloroquine-induced QT. ${ }^{37}$ 
Therefore, QT prolongation inconsistently predicts VAs in COVID-19 patients,, ${ }^{3,10,35}$ likewise hydroxychloroquine is rarely associated with malignant arrhythmias $(<1 \%) .{ }^{10,35,37}$ ST-T wave changes seemingly are not related to $\mathrm{VAs}^{45}$; however, elevated markers of cardiac injury (troponin, natriuretic peptide) and systemic inflammation (ie, C-reactive protein, interleukin-6) are significantly higher in patients presenting lifethreatening arrhythmias, ${ }^{3,8,9,46,47}$ nonetheless it is not univocally acknowledged. ${ }^{10}$ Differently, a high dose of pressors seems to correlate with VAs incidence, both due to adrenergic stimulation and also for an implication of severe cardiogenic shock, whereas the value of admission left ventricular function is controversial. ${ }^{8-11,15,43}$

\section{THERAPEUTIC OPTIONS}

If supportive management, including correction of electrolyte and acid/base derangement, fluid repletion, blood transfusion, coronary or pulmonary reperfusion, is not adequate, rationale antiarrhythmic strategies should be adopted. Sedatives and anesthetics should be titrated down or discontinued when identified as the cause of bradycardia or QT prolongation, ${ }^{4}$ and standard dose of beta blockers is certainly useful compatibly with the cardiac output.

Thirty-four percent of the 447 respondents $(n=150)$ to a global survey (March-April 2020) admitted to using amiodarone for VAs treatment, whereas $15 \%(n=64)$ disclosed having used lidocaine or mexiletine for the same purpose. Other class III agents (sotalol and dofetilide) were rarely reported. ${ }^{48}$ Pulmonary and hepatic toxicity probably refrained most physicians from adopting amiodarone in secondary prevention in patients with a concomitant viral respiratory syndrome often complicated by liver dysfunction. ${ }^{49}$

According to some authors, lung toxicity is more likely to occur in ICU patients in which the oxidative damage of high oxygen partial pressure potentiates the free radicals derived from the iodine accumulated in the alveoli. ${ }^{50}$ However, it is worth highlighting that acute lung toxicity is an adverse event reported anecdotally ${ }^{51,52}$; rather, a cumulative dose of $150 \mathrm{~g}$, equivalent to $400 \mathrm{mg}$ daily for 3 months, or $200 \mathrm{mg}$ for more than 18 months are associated with pulmonary injury. ${ }^{53-56}$

On the contrary, liver toxicity requires as high as $300 \mathrm{~g}$ of cumulative dose, ${ }^{57}$ but according to some German scholars, one-third of the SARS-CoV-2 patients admitted in ICU has shock liver, which may compromise amiodarone metabolism. ${ }^{45}$

In our opinion, the vast experience in daily practice and the existing literature in non-COVID scenarios is more than sufficient to state that amiodarone is efficacious for malignant arrhythmias in COVID-19 patients. Despite isolated warning reports about lung and hepatic toxicity in some subjects with new coronavirus infection, ${ }^{58-60}$ the legitimate concern should be the risk of liver injury and of QT prolongation secondary to drug-drug interaction with antimicrobials ${ }^{36,40}$; thus, we think that amiodarone should be cautiously dosed in patients with extreme transaminitis, but still be preferred to other more torsadogenic class III agents. Furthermore, in the case of long QT (>550 ms), the treatment should switch to $\mathrm{lb}$ agents, which can shorten the repolarization. ${ }^{61}$

Interestingly, amiodarone exhibits pleiotropic effects that can interfere with SARS-CoV-2 infection, by altering the ion channels of the endosomal vesicles. ${ }^{62}$ Also, it prevents cytokines production supposedly through the same mechanism in lymphocytes in vivo, ${ }^{63}$ and additionally presents scavenging effects of oxygen free radicals in vitro. ${ }^{64}$ In light of such anti-inflammatory antioxidant properties, amiodarone has been proposed for the treatment of symptomatic patients; besides a single case report, ${ }^{65}$ a randomized trial in comparison with verapamil is currently on recruiting (ReCOVery-SIRIO, ClinicalTrials.gov identifier: NCT04351763). ${ }^{66,67}$

ICDs and endocardial ablation should be recommended in agreement with the international guidelines, ${ }^{68-70}$ and when available, a remote navigation system should be used for the ablation to minimize the exposure of the medical staff. ${ }^{2}$

\section{SUMMARY}

SARS-CoV-2 is a systemic disease that can also impair the electrical stability of the ventricles. Although a direct cardiac infection by the virus is plausible, the host's systemic neuroinflammatory response in addition to metabolic disorders are the main triggers of $V A s$. The physician should be aware that subjects with pre-existing cardiac disease, admitted to ICU, requiring pressor support are more at risk of developing malignant arrhythmias. Therefore, strict monitoring of drugs interactions and precipitating factors (such as hypoxemia, hypokalemia, acidosis) is essential for primary prevention. Amiodarone is generally safe for the secondary prophylaxis of sustained events, and also might show unexplored antiviral/antiinflammatory effects in human. Intravenous procainamide, lidocaine, or oral mexiletine are alternatives, albeit the evidence is limited. Contrarily, sotalol and dofetilide should be discouraged, because the more significant torsadogenic effect can be detrimental in such a delicate scenario. Lastly, substrate ablation is 
recommended in case of refractory episodes, possibly by using a remote navigation system to minimize the contact with the providers.

\section{CLINICS CARE POINTS}

- Ventricular arrhythmias prevail in less than $10 \%(<1-8 \%)$ of the patients with acute COVID-19 infection, including premature ventricular contractions and life-threatening events.

- The cause is multifactorial and includes direct virus interaction with cardiomyocytes, the effect of interleukins, neurohormonal output, pre-existing cardiac disease, metabolic disorders, iatrogenic toxicity, and latent congenital arrhythmic disorders precipitated by the systemic illness.

- Although VAs are associated with increased mortality, it does not imply that they are the primary cause of death. In contrast, they express the terminal event of a severe systemic metabolic and inflammatory catastrophe.

- In absence of reversible causes (ie, QTprolonging agents, hypoxemia, hypokalemia), amiodarone is generally safe if other parameters are monitored (ie, liver function) and could theoretically exhibit pleiotropic beneficial effects on the infection itself. Class I agents represent valid alternatives, and ablation should be performed following the international guidelines, possibly with the help of a robotic navigation system to maximize contact isolation.

\section{DISCLOSURE}

Dr A. Natale has received speaker honoraria from Boston Scientific, Biosense Webster, St. Jude Medical, Biotronik, and Medtronic; and is a consultant for Biosense Webster, St. Jude Medical, and Janssen. Dr L. Di Biase is a consultant for Biosense Webster, RMG, Stereotaxis, Boston Scientific, and Abbott. Dr L. Di Biase received speaker honoraria/travel from Medtronic, Atricure, and Biotronik. All other authors have reported that they have no relationships relevant to the contents of this article to disclose.

\section{REFERENCES}

1. Available at: https://coronavirus.jhu.edu/map.html. Accessed on June 12, 2021.
2. Mitacchione G, Schiavone M, Gasperetti A, et al. Ventricular tachycardia storm management in a COVID-19 patient: a case report. Eur Heart J Case Rep 2020;4(FI1):1-6.

3. Elsaid O, McCullough PA, Tecson KM, et al. Ventricular fibrillation storm in coronavirus 2019. Am J Cardiol 2020;135:177-80.

4. O'Brien C, Ning N, McAvoy J, et al. Electrical storm in COVID-19. JACC Case Rep 2020;2(9):1256-60.

5. Chang D, Saleh M, Garcia-Bengo Y, et al. COVID-19 infection unmasking brugada syndrome. Heartrhythm Case Rep 2020;6:237-40.

6. Tsimploulis A, Rashba EJ, Rahman T, et al. Fan R Medication unmasked Brugada syndrome and cardiac arrest in a COVID-19 patient. Heartrhythm Case Rep 2020;6(9):554-7.

7. Bhatla A, Mayer MM, Adusumalli S, et al. COVID-19 and cardiac arrhythmias. Heart Rhythm 2020;17(9): 1439-44.

8. Guo T, Fan Y, Chen M, et al. Cardiovascular implications of fatal outcomes of patients with coronavirus disease 2019 (COVID-19). JAMA Cardiol 2020; 5(7):811-8.

9. Wetterslev M, Jacobsen PK, Hassager C, et al. Cardiac arrhythmias in critically ill patients with coronavirus disease 2019: a retrospective populationbased cohort study. Acta Anaesthesiol Scand 2021;65(6):770-7.

10. Peltzer B, Manocha KK, Ying X, et al. Arrhythmic complications of patients hospitalized with COVID19: incidence, risk factors, and outcomes. Circ Arrhythm Electrophysiol 2020;13(10):e009121.

11. Piro A, Magnocavallo M, Della Rocca DG, et al. Management of cardiac implantable electronic device follow-up in COVID-19 pandemic: Lessons learned during Italian lockdown. J Cardiovasc Electrophysiol 2020;31(11):2814-23.

12. Turagam MK, Musikantow D, Goldman ME, et al Malignant arrhythmias in patients with COVID-19: incidence, mechanisms, and outcomes. Circ Arrhythm Electrophysiol 2020;13(11):e008920.

13. Liu K, Fang YY, Deng Y, et al. Clinical characteristics of novel coronavirus cases in tertiary hospitals in Hubei Province. Chin Med J (Engl) 2020;133(9):1025-31.

14. Lanza GA, De Vita A, Ravenna SE, et al. Electrocardiographic findings at presentation and clinical outcome in patients with SARS-CoV-2 infection. Europace 2021;23(1):123-9.

15. Peretto G, Villatore A, Rizzo S, et al. The spectrum of COVID-19-associated myocarditis: a patient-tailored multidisciplinary approach. J Clin Med 2021;10(9): 1974.

16. Ho JS, Sia CH, Chan MY, et al. Coronavirus-induced myocarditis: a meta-summary of cases. Heart Lung 2020;49(6):681-5.

17. Siripanthong B, Nazarian S, Muser D, et al. Recognizing COVID-19-related myocarditis: the possible 
pathophysiology and proposed guideline for diagnosis and management. Heart Rhythm 2020;17(9): 1463-71.

18. Della Rocca DG, Santini L, Forleo GB, et al. Novel perspectives on arrhythmia-induced cardiomyopathy: pathophysiology, clinical manifestations and an update on invasive management strategies. Cardiol Rev 2015;23(3):135-41.

19. Siddiq MM, Chan AT, Miorin L, et al. Physiology of cardiomyocyte injury in COVID-19. medRxiv 2020; 2020:11.

20. Bulfamante GP, Perrucci GL, Falleni M, et al. Evidence of SARS-CoV-2 transcriptional activity in cardiomyocytes of COVID-19 patients without clinical signs of cardiac involvement. Biomedicines 2020; 8(12):626.

21. Wichmann D, Sperhake JP, Lütgehetmann M, et al. Autopsy findings and venous thromboembolism in patients with COVID-19: a Prospective cohort study. Ann Intern Med 2020;173(4):268-77.

22. Puntmann VO, Carerj ML, Wieters I, et al. Outcomes of cardiovascular magnetic resonance Imaging in patients Recently Recovered from coronavirus disease 2019 (COVID-19). JAMA Cardiol 2020;5(11): $1265-73$.

23. Haque R, Kan H, Finkel MS. Effects of cytokines and nitric oxide on myocardial E-C coupling. Basic Res Cardiol 1998:93(Suppl 1):86-94.

24. Lazzerini PE, Laghi-Pasini F, Bertolozzi I, et al. Systemic inflammation as a novel QT-prolonging risk factor in patients with Torsades de Pointes. Heart 2017; 103:1821-9.

25. Zhabyeyev P, Oudit GY. Sickle cell disease, interleukin-18, and arrhythmias. Blood 2021;137(9): 1138-9.

26. Tsai YN, Hsiao YW, Lin SF, et al. Proinflammatory cytokine modulates Intracellular calcium handling and Enhances ventricular arrhythmia susceptibility. Front Cardiovasc Med 2021;8:623510.

27. Di Biase L, Romero J, Zado ES, et al. Variant of ventricular outflow tract ventricular arrhythmias requiring ablation from multiple sites: Intramural origin. Heart Rhythm 2019;16(5):724-32.

28. Solaimanzadeh J, Freilich A, Sood MR. Ventricular tachycardia with epicardial and pericardial fibrosis 6 months after resolution of subclinical COVID-19: a case report. J Med Case Rep 2021;15(1):305.

29. Mitrani RD, Dabas N, Goldberger JJ. COVID-19 cardiac injury: implications for long-term surveillance and outcomes in survivors. Heart Rhythm 2020; 17(11):1984-90.

30. Della Rocca DG, Magnocavallo M, Lavalle C, et al. Evidence of systemic endothelial injury and microthrombosis in hospitalized COVID-19 patients at different stages of the disease. J Thromb Thrombolysis 2021;51(3):571-6.
31. Pellegrini D, Kawakami R, Guagliumi G, et al. Microthrombi as a major cause of cardiac injury in COVID19: a pathologic study. Circulation 2021;143(10): $1031-42$.

32. D'Ascenzo F, De Filippo O, Borin A, et al. Impact of COVID-19 pandemic and infection on in hospital survival for patients presenting with acute coronary syndromes: a multicenter registry. Int $J$ Cardiol 2021;332:227-34.

33. Luqman N, Sung RJ, Wang CL, et al. Myocardial ischemia and ventricular fibrillation: pathophysiology and clinical implications. Int J Cardiol 2007; 119(3):283-90.

34. Tazmini K, Frisk M, Lewalle A, et al. Hypokalemia Promotes arrhythmia by distinct mechanisms in atrial and ventricular myocytes. Circ Res 2020; 126(7):889-906.

35. Sealy WC, Young WG Jr, Harris JS. Studies on cardiac arrest: the relationship of hypercapnia to ventricular fibrillation. J Thorac Surg 1954;28(5): 447-62.

36. Gettes LS. Electrolyte abnormalities underlying lethal and ventricular arrhythmias. Circulation 1992; 85(1 Suppl):170-6.

37. Chen Q, Xu J, Gianni C, et al. Simple electrocardiographic criteria for rapid identification of wide QRS complex tachycardia: the new limb lead algorithm. Heart Rhythm 2020;17(3):431-8.

38. Schrezenmeier E, Dörner T. Mechanisms of action of hydroxychloroquine and chloroquine: implications for rheumatology. Nat Rev Rheumatol 2020;16(3): 155-66.

39. Saleh M, Gabriels J, Chang D, et al. Effect of chloroquine, hydroxychloroquine, and azithromycin on the corrected QT interval in patients with SARS-CoV-2 infection. Circ Arrhythm Electrophysiol 2020;13(6): e008662.

40. Gasperetti A, Biffi M, Duru F, et al. Arrhythmic safety of hydroxychloroquine in COVID-19 patients from different clinical settings. Europace 2020;22(12): 1855-63.

41. Zhang M, Xie M, Li S, et al. Electrophysiologic studies on the risks and potential mechanism underlying the Proarrhythmic nature of azithromycin. Cardiovasc Toxicol 2017;17(4):434-40.

42. Marmolejo-Murillo LG, Aréchiga-Figueroa IA, Moreno-Galindo EG, et al. Chloroquine blocks the Kir4.1 channels by an open-pore blocking mechanism. Eur J Pharmacol 2017;800:40-7.

43. Yang Z, Prinsen JK, Bersell KR, et al. Azithromycin causes a novel Proarrhythmic syndrome. Circ Arrhythm Electrophysiol 2017;10(4):e003560.

44. Chorin E, Wadhwani L, Magnani S, et al. QT interval prolongation and torsade de pointes in patients with COVID-19 treated with hydroxychloroquine/azithromycin. Heart Rhythm 2020;17:1425-33. 
45. Romero J, Alviz I, Parides M, et al. T-wave inversion as a manifestation of COVID-19 infection: a case series. J Interv Card Electrophysiol 2020;59(3):485-93.

46. Lazzerini PE, Boutjdir M, Capecchi PL. COVID-19, arrhythmic risk, and inflammation: Mind the Gap. Circulation 2020;142(1):7-9.

47. Zylla MM, Merle U, Vey JA, et al. Predictors and Prognostic implications of cardiac arrhythmias in patients hospitalized for COVID-19. J Clin Med 2021; 10(1):133.

48. Gopinathannair R, Merchant FM, Lakkireddy DR, et al. COVID-19 and cardiac arrhythmias: a global perspective on arrhythmia characteristics and management strategies. J Interv Card Electrophysiol 2020;59(2):329-36.

49. Roedl K, Jarczak D, Drolz A, et al. Severe liver dysfunction complicating course of COVID-19 in the critically ill: multifactorial cause or direct viral effect? Ann Intensive Care 2021;11(1):44.

50. Ashrafian H, Davey P. Is amiodarone an underrecognized cause of acute respiratory failure in the ICU? Chest 2001;120(1):275-82.

51. Argyriou M, Hountis P, Antonopoulos N, et al. Acute fatal post-CABG low dose amiodarone lung toxicity. Asian Cardiovasc Thorac Ann 2007;15(6):e66-8.

52. Baumann H, Fichtenkamm $P$, Schneider $T$, et al. Rapid onset of amiodarone induced pulmonary toxicity after lung lobe resection - a case report and review of recent literature. Ann Med Surg (Lond) 2017;21:53-7.

53. Ott MC, Khoor A, Leventhal JP, et al. Pulmonary toxicity in patients receiving low-dose amiodarone. Chest 2003;123:646-51.

54. Terzo F, Ricci A, D'Ascanio M, et al. Amiodaroneinduced pulmonary toxicity with an excellent response to treatment: a case report. Respir Med Case Rep 2019;29:100974.

55. Camus P, Martin WJ II, Rosenow EC III. Amiodarone pulmonary toxicity. Clin Chest Med 2004;25:65-75.

56. Tarantino N, Della Rocca DG, Faggioni M, et al. Epicardial ablation complications. Card Electrophysiol Clin 2020;12(3):409-18.

57. Hussain N, Bhattacharyya A, Prueksaritanond S. Amiodarone-induced cirrhosis of liver: what predicts mortality? ISRN Cardiol 2013;2013:617943.

58. Azraai M, McMahon M, Dick R. Case report of amiodarone-associated allergic pneumonitis amidst the COVID-19 pandemic. Rev Cardiovasc Med 2021;22(1):181-4.

59. Kow CS, Hasan SS. Amiodarone in COVID-19: let's not forget its potential for pulmonary toxicity. Eur $\mathrm{J}$
Prev Cardiol 2020. https://doi.org/10.1093/eurjpc/ zwaa086. zwaa086.

60. Schmit G, Lelotte J, Vanhaebost J, et al. The liver in COVID-19-related death: Protagonist or Innocent Bystander? Pathobiology 2021;88(1):88-94.

61. Mitra RL, Greenstein SA, Epstein LM. An algorithm for managing QT prolongation in coronavirus disease 2019 (COVID-19) patients treated with either chloroquine or hydroxychloroquine in conjunction with azithromycin: possible benefits of intravenous lidocaine. Heartrhythm Case Rep 2020;6(5):244-8.

62. Stadler K, Ha HR, Ciminale V, et al. Amiodarone alters late endosomes and inhibits SARS coronavirus infection at a post-endosomal level. Am J Respir Cell Mol Biol 2008;39:142-9.

63. Ito $H$, Ono K, Nishio R, et al. Amiodarone inhibits interleukin 6 production and attenuates myocardial injury induced by viral myocarditis in mice. Cytokine 2002; 17:197-202.

64. Ide T, Tsutsui H, Kinugawa S, et al. Amiodarone protects cardiac myocytes against oxidative injury by its free radical scavenging action. Circulation 1999; 100:690-2.

65. Castaldo N, Aimo A, Castiglione V, et al. Safety and efficacy of amiodarone in a patient with COVID-19. JACC Case Rep 2020;2(9):1307-10.

66. Sanchis-Gomar F, Lavie CJ, Morin DP, et al. Amiodarone in the COVID-19 Era: treatment for symptomatic patients only, or drug to prevent infection? Am J Cardiovasc Drugs 2020;20(5):413-8.

67. Available at: https://clinicaltrials.gov/ct2/show/ NCT04351763. Accessed on July 5, 2021.

68. Cronin EM, Bogun FM, Maury P, et al. 2019 HRS/ EHRA/APHRS/LAHRS expert consensus statement on catheter ablation of ventricular arrhythmias: Executive summary. J Arrhythm 2020;36(1):1-58.

69. Priori SG, Blomström-Lundqvist C, Mazzanti A, et al, ESC Scientific Document Group. 2015 ESC guidelines for the management of patients with ventricular arrhythmias and the prevention of sudden cardiac death: the task Force for the management of patients with ventricular arrhythmias and the prevention of sudden cardiac death of the European society of Cardiology (ESC). Endorsed by: association for European Paediatric and congenital Cardiology (AEPC). Eur Heart J 2015;36(41):2793-867.

70. Briceño DF, Romero J, Villablanca PA, et al. Longterm outcomes of different ablation strategies for ventricular tachycardia in patients with structural heart disease: systematic review and meta-analysis. Europace 2018;20(1):104-15. 